\title{
Del mérito y el rango
}

\section{Merit and grade}

En esta etapa que estamos viviendo, con más tiempo para otras actividades como la reflexión y la lectura, encontré en estas líneas escritas hace cien años conceptos que hemos perdido o que cada vez ejercitamos con menor frecuencia. El valor de la palabra, la ética, el honor. Los seres humanos tenemos características físicas que nos identifican y otras adquiridas o aprendidas a través del tiempo. Entre ellas, la educación, el conocimiento y la voluntad de progresar. En los últimos setenta años, estas se han ido perdiendo, convirtiéndose a veces en rara avis de la vida cotidiana.

Las continuas "urgencias" de hoy nos hacen perder el objetivo final de nuestro paso por este mundo.

Por todo ello, a continuación de esta introducción, bien vale reflexionar sobre este fragmento de una de las obras de un gran médico argentino: José Ingenieros (1877-1925).

"No van siempre juntos, ni guardan armónica proporción. El rango se recibe, es adventicio y su valor fluctúa con la opinión que le son extrínsecas de los demás, pues necesita la convergencia de sanciones sociales que le son extrínsecas. El mérito se conquista, vale por sí mismo y nada puede amenguarlo, porque es una síntesis de virtudes individuales intrínsecas. Cuanto mayor es la inmoralidad social, más grande es su divorcio. El mérito sigue siendo afirmación de aisladas excelencias, el rango se convierte en premio a la complicidad en el mal.

Los jóvenes que olvidan esos distingos viven genuflexos, rindiendo homenaje al rango ajeno para avanzar el propio. Cegados por bastos apetitos llegan a creer al fin que los funcionarios de más bulto son los hombres de mayor mérito y se acostumbran a medirlos por el número de favores que puedan dispensar.

El mérito está en ser y no parecer. El mérito del pensador del sabio, del energeta, del artista es el mismo en la cumbre que en el llano, en la gloria o en la adversidad, en la opulencia o en la miseria. En las generaciones sin ideales se advierte una sorda confabulación de mediocridades contra el mérito. Todos los incapaces de crear su propio destino conjugan sus impotencias y las condensan en una moral burocrática que infecta a la sociedad entera.

El hábito de ver tasar a los demás por los títulos que ostentan despierta en todos un obsesivo anhelo de poseerlos y hace olvidar que el Estado puede usar en su provecho la competencia individual, pero no puede conferirla a quien carece de ella. En el engranaje de la burocracia no es necesariamente economista el profesor de economía política, ni astrónomo el director del observatorio, ni historiador el archivero, ni escritor el secretario, como tampoco es fuerza que sea estadista el gobernante. Las más de esas personas respetadas por su rango ruedan al anónimo el día mismo en que lo pierden; en esa esa hora se mide la vanidad de su destino por el empeño con que sus domésticos alaban a los nuevos amos que los sustituyen.

Desdeñe la juventud esos falsos valores creados por la complicidad en el hartazgo. Burlándose de ellos, el hombre libre es un amo natural de todos los necios que los admiran. Respetando la virtud y el mérito, antes que el rango y la influencia, aprenderán los jóvenes a emanciparse de la servidumbre moral.

Áspero es todo sendero que se asciende sin cómplices. La rebeldía de los caracteres firmes humilla a los que se adaptan con blandura de molusco; la originalidad de los artistas que crean subleva a los académicos cautelosos; el verbo nuevo de los sabios desconcierta a los glosadores de la rutina común.

Sobresalir es incomodar; las medianías se creen insuperables y no se resignan a celebrar el mérito de quien las desengańa. Por eso tener ideales es vivir pensando en el futuro, sin acomodarse al azar de la hora presente: para adelantarse a esta, es menester vivir desorbitados, pues quien se entrega a la moda que pasa, envejece y muere con ella. Si el mérito culmina en creaciones geniales, ellas son de todos los tiempos y para todos los pueblos".

José Ingenieros. Médico. Las fuerzas morales (1918-1923) 